\title{
BUILDING COALITIONS: Mobilizing the Community
}

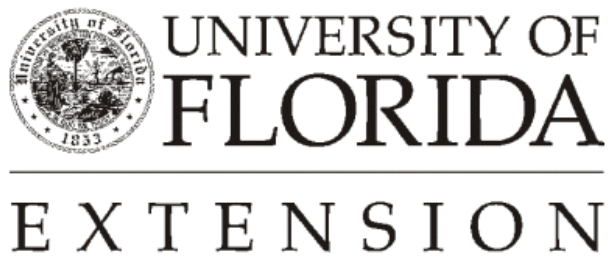

Institute of $\mathbf{F}_{\text {ood and }} \mathbf{A}_{\text {gricultural }} \mathbf{S}_{\text {ciences }}$ 
Communities can mobilize to work for changes that will benefit the social, emotional, financial and physical needs of citizens.

Each community is a microcosm of a nation. It includes a dozen republics. It is the educational and professional groups, members of fraternal organizations, women's and garden clubs. It is business and industry, civic leaders, youth, media, labor and church leaders and the elderly. It is the community at large, which may react differently as a group than its members would as individuals. (White, 1 )

Mobilizing the community begins when:

- $\quad$ Concerned citizens organize to take a stand.

- $\quad$ Needed community changes are determined.

- $\quad$ The public is concerned about the problems and need for collaboration among the community groups and individuals.

- $\quad$ The community at large is involved in the situation.

- $\quad$ Emerging community leaders are recognized and encouraged.

- $\quad$ The efforts for change are kept going after the coalition is ended.(Owen and Miller)

\section{Prerequisite for Mobilization}

When individuals and organizations come together to work on an issue, it is common to see them scramble over "turf" issues and for multiple, unrelated programs to result. The group needs to come to a consensus of moving toward collaboration. For this to happen, there needs to be time allowed for trust building. This is where the different individuals and organizations examine their capabilities and motivations. Ideas are exchanged, problems resolved and participants learn to give and take. (Dye and Wood 1981, 2)

For successful coalitions to happen, working relationships must be developed between each member of the coalition and the groups must put the plan into practice. Coordinating mechanisms can help.

In addition, it is necessary that any collaborative effort be as open as possible. Involve the broadest circle of agencies and organizations to encourage collaboration around the common issue. It is essential that any collaborative effort does not threaten or duplicate existing efforts on the same issue. The coalition also must recognize that the public will be pushing for action and results. 


\section{What is Needed to Mobilize a Community?}

- Concerned citizens ready to take a stand, say they want something different and are willing to work to see it accomplished.

- $\quad$ Emerging leadership that inspires and guides the project.

- A common community vision of the results.

- Involved people who recognize that the means to achieve their goals will vary but who support the common goal.

- Recognition and encouragement of those who contribute to reaching the goal.

- Specific plans and goals to reduce impact of at-risk situations.

- Leadership that encourages, builds and finds strategies but doesn't become the focus of the situation.

- Recognition that human relationships are important.

- $\quad$ Time. (Owen and Miller, 7-8)

\section{Who Needs to be Involved?}

The natural allies for mobilization are those persons who have a common interest in an issue. This can include community-minded individuals and all persons and groups affected by the issue. It is important that the group have linkages either by representation or delegation to the power structure, government agencies, key communicators, advisory boards, local businesses and educational institutions.

Membership in a community coalition falls into three categories:

- Activists who take an active role and provide leadership, write grants and serve on subcommittees and steering committees.

- Helpers who work on a limited basis or on specific designated tasks such as letter writing, newsletter distribution, etc.

- Communicators who share the work of the coalition to the outside through educational sessions and coalitions with other groups. (Burghard) 


\section{Strategies to Use}

Various strategies are used to form coalitions. It has worked successfully to form an organization of the diverse groups who have a common interest, identify and recruit potential members, and establish a governing board. The coordinator of the group facilitates the decision-making process and helps members work together. Due to coordinating effort and visibility, formal groups are able to carry out large projects. Unfortunately, this strategy requires more time and effort to develop and operate.

Another strategy is less formal and can be applied to a community of any size. It targets particular segments of the population through building informal networks.

\section{Methods}

Various methods for mobilization can be used, including a town meeting approach or speak-outs. Their common factors are that they are process oriented activities and include individual, followup and concrete portions.

The initial large meeting allows for education and suggests the democratic process. Sign-up sheets at this meeting will help with the next phase, which is done by subcommittees who follow through on assignments and issues. It is here the individual is recognized and appreciates the openness. Finally, there is the concrete work of the subcommittee that shows the community they are working for change. (Burghard 1986, 40)

\section{Public Relations Plan}

When launching a new program or mobilizing the public to action on a community need, an effective, comprehensive public relations plan must be developed. This generates greater support and involvement in programs and activities that address the need. A new program must be recognized and perceived as an asset to the community.

Barbara L. White, Ph.D. says an effective public relations plan will help those who are concerned contribute to the creation of positive attitudes where none exist. She also notes that it will intensify existing positive attitudes, convert existing negative attitudes and sometimes neutralize persistent negative attitudes. Sound public relations programs are planned for before, during and after a program's introduction. The objective is to sell the program, to gain support and to maximize involvement. The program must be visible, viewed as a necessity and appreciated for what it offers. (White, 2-3)

To add a competitive edge to the initiative, program publicity must go through the following stages:

1. Unveil the program-not once but literally hundreds of times.

2. Promote the ad campaign behind the program. 
3. Tell the story of the people who developed it.

4. Report on community acceptance.

5. Report on the community's reactions.

6. Tell the story of the program's success.

7. Emphasize advantages to the community.

8. Report on trends.

9. Tell success stories of other states and other communities. (White, 3-4)

Guidelines for a local community public relations plan include:

1. Select members for a public relations task force who represent the groups involved.

2. Appoint a director of the task force.

3. Conduct an awareness/opinion/attitude survey.

4. Analyze the survey.

5. Conduct workshops for all those involved in the public relations component of the program.

6. Develop a multiple-year mobilization plan. (White, 4-5)

A public relations task force reaches the public in two ways:

- $\quad$ By person-to-person contact through speeches, meetings with civic leaders, annual meetings, special events, personal letters, employee contacts, participation in civic affairs, support of education programs, religious assemblies, public service events, open houses and ceremonial affairs.

- $\quad$ By use of local media such as television, radio, newspapers, advertising by direct mail, newsletters, billboards, displays, films, brochures, exhibits, theater and sports programs, business signs, etc. (White,4) 
Model Format of Mobilization Plan

\begin{tabular}{|c|c|c|c|c|c|c|c|}
\hline & \multirow{2}{*}{\multicolumn{2}{|c|}{ Public Mobilization Plan }} & \multicolumn{5}{|c|}{ Implementation Schedule } \\
\hline & & & 2002 & 2003 & 2004 & 2005 & 2006 \\
\hline A. & $\begin{array}{l}\text { al Audiences } \\
\text { Graphic pres } \\
\text { handout to re } \\
\text { I. } \\
\text { II. } \\
\text { III. } \\
\text { IV. } \\
\text { V. } \\
\text { VI. } \\
\text { VII. } \\
\\
\text { Public relatio } \\
\text { I. } \\
\text { II. } \\
\\
\text { III. } \\
\text { IV. } \\
\text { V. } \\
\text { VI. }\end{array}$ & $\begin{array}{l}\text { ntation with brochure } \\
\text { oresentatives of: } \\
\text { Business community } \\
\text { Educational systems } \\
\text { Law enforcement } \\
\text { Human social services } \\
\text { Government } \\
\text { Churches } \\
\text { Other groups as } \\
\text { determined by the coalition } \\
\text { ns packets to: } \\
\text { Opinion Speakers } \\
\text { Speakers bureaus in place } \\
\text { at various businesses, } \\
\text { organizations } \\
\text { Public service } \\
\text { announcements on radio } \\
\text { and television } \\
\text { News items to newsletters } \\
\text { of various businesses } \\
\text { Billboards } \\
\text { Video/slide presentations }\end{array}$ & & & & & \\
\hline & $\begin{array}{l}\text { S-Study } \\
\text { I-Implement }\end{array}$ & $\begin{array}{l}\text { E-Evaluate } \\
\text { R-Recommer }\end{array}$ & dation & & get Ite & & $\begin{array}{l}\text { ilot } \\
\text { ngoing }\end{array}$ \\
\hline
\end{tabular}

\section{Developing a Mobilization Plan}

A mobilization plan should raise the public's consciousness about the program, garner the support of the citizens and involve an effective percentage of the population in active program participation. (White, 2) 
The early focus of any public mobilization plan should:

- Determine attitudes toward the problem.

- $\quad$ Assess what the public expects.

- $\quad$ Provide adequate information about the far-reaching effects of the problem.

- Develop effective information that acts as a catalyst for community support and involvement. (White, 2)

White recommends that a mobilization plan have specific goals, objectives, activities and timeliness. A multiple-year plan should:

- $\quad$ Assess public awareness, opinions and attitudes.

- $\quad$ Evaluate programs and services being offered.

- $\quad$ Study programs and services to be offered.

- $\quad$ Determine resources, both internal and external.

- $\quad$ Assess "environmental" factors:

1) Legislature

2) Public awareness/opinions/attitudes

- $\quad$ Determine campaign theme.

- Develop campaign print materials.

- $\quad$ Develop campaign visual materials.

- Develop packet of materials for the following:

1) Local opinion makers

2) Local speakers bureau

3) Key communicators in the community (White, 9)

\section{Continuing Mobilization in Established Groups}

Established groups and coalitions have a different set of concerns to address.

Problems. The most common problems facing established grassroots groups are a self-satisfied inwardness that may over time breed marginality, a lack of outward growth and a leaning for elitist or 
undemocratic functioning. An easy way to identify the early signs of inwardness is the tendency for group members to use first names, abbreviations and shorthand words.

Helps. To prevent stagnation and continue group outreach, organizers must serve as role models and carefully, but consistently, intervene when abbreviations and shorthand words are used in the group. Once group outreach is dropped, it is difficult to reestablish. Subcommittee reports should always give brief information on why the committee was formed. The emphasis on procedural items for explanation, clarity in communication and clear terminology will speak to new people of the group's commitment to growth and their desire for newcomers.

Older members of established groups also have needs to be met. They may need to feel their work is worthwhile by public validation. Make certain that part of the group's activities include some form of education and development to keep members aware of larger group goals, concerns and issues.

A final issue for established groups to address initially is the nature of its leadership. The greater the shared decision-making, the greater the long-term benefits for both membership and group. One structural issue to work toward is limiting a person's position as lead of the organization to no more than two years. Also, no one in the group should be excused from performing all the tasks involved in the operation of the group. (Burghard 1986, 42-45)

\section{Barriers to Mobilization}

Some success of any community mobilization effort lies in how well opposition, criticism and other barriers are met. To sustain the mobilization effort, be honest, clear, factual and timely. Focus on the continuing assessment of communication needs, involving coalition members and community citizens on all levels. Make certain staff and public participants (those involved in publicly mobilizing the program) are still committed to it implementation. (White, 13)

"Turfwars" (who takes credit for program results) and pecking order can be principal roadblocks to successful collaboration and community mobilization. Best results come when all groups involved jointly take credit and share in the results of the mobilization. (Quick, Flashman and Gibeaux, 73)

A community must be approached cautiously to figure out centers of interaction and who the natural helpers and gatekeepers are to help facilitate awareness. Gottlieb (1974) emphasizes that natural helpers should not be "professionalized" through training or they may have less caring, concern and help. To be fully successful, mobilizers cannot afford to be insensitive to, or ignorant of, natural helping systems as they are at the heart of the sense of community. (Murray and Keller, 153-154)

Cultural differences in the community can be a barrier to mobilization bringing conflict and misunderstanding.

Another barrier can be the lack of quick adjustments to unforeseen problems. 


\section{Enhancing Mobilization}

Much can be done to enhance community mobilization. Guidelines for beginning groups include: (White,12)

- If a basic need is satisfied, the group, organization or individual will not be moved by an appeal to that need.

- If a basic need is not satisfied, that need will motivate the group, organization or individual, but only until it is satisfied.

- If a lower need is satisfied, a group, organization or individual will not be moved by an appeal to a higher need, though the higher need is also unsatisfied.

- A group, organization or individual is always open to a creative challenge, provided they feel secure about basic needs.

Know the groups, the organizations and the individuals you hope to activate. Do not treat individuals in a group as though they are all the same. Factors that guarantee success in motivation are: (White, 12)

- $\quad$ Relevance - The program is based on what the public cares about.

- Convenience - It easy for the public to participate.

- $\quad$ Publicity - Let people know what is planned.

- Commitment - A successful program demands time and commitment by the program and public relations staff, but there is always a clear purpose and goal directing the effort.

Other tips for enhancing community mobilization include:

- Set priorities for approaching various audiences for support and evaluate effectiveness with specific audiences. (Thomas 1989, 278)

- $\quad$ Actively recruit key people. (Thomas 1989, 281)

- Develop aggressive public relations programs.

- $\quad$ Establish an identity for the program.

- Realize that community acceptance increases considerably with program longevity. (Murray and Keller, 139) 
- $\quad$ Have a focused mission. (Dye and Wood 1981, 8)

- $\quad$ Respect the time commitments involved by group members and audiences being mobilized. (Dye and Wood 1981, 11)

- $\quad$ Develop linkage agents. (Thomas, Hart and Smith 1989, 278)

\section{Payoffs}

Community mobilization through coalitions and groups can have high payoffs for communities in one or more ways:

- $\quad$ Organizations and programs at the community level improve services, move into creative new ventures, do things together they could not do alone and gain courage and support to take risks that they might hesitate to take on their own. (Dye and Wood 1981, 12,13)

- $\quad$ Communities that have grown weary of trying to solve problems with outdated procedures can restore confidence and goodwill and be empowered to develop possibilities, resources and alternatives.

- $\quad$ Communities increase their ability to attract financial support from public and private sources.

- $\quad$ Communities acquire the distinct possibility of true prevention and early intervention. (Murray and Keller, 155)

- $\quad$ Community corporate planning produces programs that are cost effective, cuts down on duplications of services and creates integrated approaches to problem solving. (Dye and Wood $1981,13)$

- $\quad$ Community involvement generates commitment.

\section{Summary}

When essential elements and conditions come together, a true sense of community evolves; one that inspires, energizes and rewards members as they resolve joint problems. Leaders take a positive stand. The diversity is recognized and used as a strength. "Community" becomes redefined as more than a place, and more than the elements that divide people. It becomes the way in which people live and work together. The result is what some would describe as a "mobilization of coalitions and collaboratives," that those who live in the community simply describe as "the way we do things in our community." (Owen and Miller, 6) 


\section{References}

Burghard, Steve. Organizing for Community Action, University of Michigan School of Social Work, Sage Publications, 1986.

Dye, Robert R., John S. Wood. "A Different Game: Collaborating to Serve youth at Risk," National Council of YMCAs, National Collaboration for Youth, Journal of Voluntary Action Research (July-December, 1981).

Heleen, Owen and Frederick T. Miller. Mobilizing Local Coalitions and Collaborations to Better Serve Children at Risk. Boston: Institute for Responsive Education and Medford, Massachusetts: Lincoln Filene Center, Tufts University.

Murray, J. Dennis and Peter A. Keller. Innovations in Rural Community Mental Health, Mansfield, Pennsylvania: Mansfield University Rural Services Institute.

Quick, Sam, Robert Flashman and Arlene Gibeaux. SOS Learning Networks: A Model of Interorganizational Cooperation. University of Kentucky.

Thomas, John, Thomas E. Hart and Stuart C. Smith. Building Coalitions, ERIC Clearinghouse on Educational Management, Eugene, Oregon, Office of Educational Research and Improvement (ED), Washington, D.C., 1989.

White, Barbara L., Ph.D. Mobilizing the Public to Better Serve Children At-Risk. Community Relations and Public Information. Jackson, Mississippi: Jackson Public Schools.

\section{Authors}

Barbara A. Brahm, Certified Home Economist, Assistant Professor, County Extension Agent, Home Economics and 4-H, Ohio Cooperative Extension Service, The Ohio State University.

Margaret E. Griffiths, Certified Home Economist, Associate Professor, Northwest District Extension Specialist, Home Economics, Ohio Cooperative Extension Service, The Ohio State University.

C) 1992 The Ohio State University

DX25: Ohio Cooperative Extension Senvice 
This series on Coalition Building was developed by The Ohio Center For Action on Coalition Development for Family and High Risk Youth, Richard Clark, Ph.D., Director. It has been adapted for County Extension Faculty in Florida to facilitate work with local and regional organizations and groups such as non-profits, cooperatives, county extension associations, and others that might benefit from a plan for working together to achieve support for mutual goals.

This document is FY502, Part 10 of the 16 part series adapted for use in Florida by Elizabeth B. Bolton, Professor, Community Development and Lisa Guion, Assistant Professor, Program Planning and Evaluation; Department of Family, Youth and Community Sciences, Florida Cooperative Extension Service, Institute of Food and Agricultural Sciences, University of Florida, Gainesville, 32611-0310.

Reprinted with permission March, 1997. Revised April, 2002.

The Institute of Food and Agricultural Sciences is an equal opportunity/affirmative action employer authorized to provide research, educational information and other services only to individuals and institutions that function without regard to race, color, sex, age, handicap, or national origin. For information on obtaining other extension publications, contact your county Cooperative Extension Service office.

Florida Cooperative Extension Service/Institute of Food and Agricultural Sciences/University of Florida/Christine Taylor Waddill, Dean 